'Breeding for Success: Diversity in Action' C.F. Mercer (ed).

Proceedings of the $13^{\text {th }}$ Australasian Plant Breeding Conference,

Christchurch, New Zealand 18-21 April 2006. pp. 738-742.

\title{
Protoplast isolation, colony formation and shoot regeneration from Lolium perenne
}

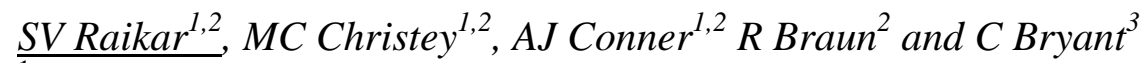

${ }^{1}$ National Centre for Advanced Bio-Protection Technologies, PO Box 84, Lincoln

University, Canterbury, New Zealand

${ }^{2}$ New Zealand Institute for Crop \& Food Research Limited, Private Bag 4704, Christchurch, New Zealand

${ }^{3}$ Pastoral Genomics, P O Box 109-185, Newmarket, Auckland, New Zealand

Abstract. Lolium perenne (ryegrass) is the most widely sown pasture grass in New Zealand providing forage for millions of sheep and cattle. Genetic improvement of Lolium species through conventional breeding has been particularly difficult because of its outbreeding and heterozygous nature. Biotechnology techniques that are not based on genetic modification technology, such as protoplast fusion, could help in the breeding of $L$. perenne as it enables the introgression of DNA (and associated desirable traits) from other species of plants that are otherwise unobtainable by conventional means. We intend to adapt this technology for $L$. perenne and report on our progress with the isolation of protoplasts, micro colony and callus formation, and shoot regeneration. Friable callus was induced from $L$. perenne seeds and used for isolation of protoplasts. After testing several combinations of enzyme mixtures at different molarities, a high yield of protoplasts $\left(1.1 \times 10^{7} \mathrm{~g}^{-1} \mathrm{FW}\right)$ with a viability of $82 \%$ has been obtained. Callus colonies were formed from protoplasts cultured on a nitrocellulose membrane over a feeder layer. Plating efficiencies of $0.1-0.2 \%$ were obtained. Regeneration of plantlets from these colonies were obtained on Linsmaier and Skoog medium supplemented with growth hormones. All the plants regenerated to date have an albino appearance.

\section{Introduction}

Lolium perenne L. (perennial ryegrass) is one of the most important forage grasses world-wide both in terms of seed sales and land area covered (Burgon et al. 1997). Its popularity is due to its high digestibility, combined with good tolerance to grazing and adequate seed production. In L. perenne, genetic improvement by conventional breeding techniques is limited by several factors. It is an obligate outbreeder which suffers from severe inbreeding depression, making crosses between and within species very unstable. It is an amphidiploid, and a long time is required to transfer traits (five to six generations), with an enormous number of progeny required to select plants with appropriate combinations of traits (Sharma et al. 2002).

Non-conventional plant breeding techniques such as tissue culture and genetic engineering using somatic and molecular hybridisations are well established. They have been used in Lolium spp. to enable gene introgression and in the production of transgenic plants (Spangenberg et al. 1995, Wang et al. 1997, Dalton et al. 1999). However, public apprehension toward recombinant DNA technologies has encouraged researchers to develop alternative methods. One such technique is the use of protoplasts for gene transfer.

Protoplasts have been used for somatic hybridisation in a range of crop plants as a first step toward genetic improvement by gene introgression. We intend to use somatic hybridisation in the breeding of $L$. perenne. In this article, we describe the isolation and culture of protoplasts, colony formation and plant regeneration from L. perenne. These 
results could be helpful in establishing a successful protoplast-to-plant regeneration system for genetic improvement of L. perenne.

\section{Material and methods}

Induction of callus and cell suspension

L. perenne L. var. Bronsyn line LG 4515A, a low endophyte variety, was obtained from Speciality Grains and Seeds, Christchurch, New Zealand. Commercial bleach 'Dynawhite' (Jasol, New Zealand) with 4.8\% 0.2 Na-hypochlorite was used as a surface sterilising agent. The L. perenne seeds were briefly immersed in $70 \%$ ethanol followed by immersion in $0.75-3.5 \%$ Na-hypochlorite (diluted from commercial bleach, Dynawhite) for 10-90 min with occasional stirring. The surface-sterilised seeds were plated on hormone-free LS (Linsmaier and Skoog 1965) medium solidified with $0.8 \%$ agar (Danisco, New Zealand) and cultured in sterile plastic containers (80 mm diameter x $50 \mathrm{~mm}$ high; Vertex Plastics, Hamilton, NZ). Ten seeds were sown in each container and cultured in darkness at $25^{\circ} \mathrm{C}$. Germinating embryos were excised after 2 days and plated on LS medium containing $5 \mathrm{mg} / \mathrm{L}$ 2,4-dichlorophenoxyacetic acid (2,4-D), 500 $\mathrm{mg} / \mathrm{L}$ casein hydrolysate, $3 \%(\mathrm{w} / \mathrm{v})$ sucrose, and solidified with $0.8 \%$ agar. The callus appearing 4-6 weeks later was maintained by subculturing on the same medium fortnightly.

Cell suspensions were initiated from this callus in $125 \mathrm{~mL}$ Erlenmeyer flasks with $35 \mathrm{~mL}$ of liquid LS medium containing $5 \mathrm{mg} / \mathrm{L} \mathrm{2,4-D.} \mathrm{The} \mathrm{flasks} \mathrm{were} \mathrm{cultured} \mathrm{at}$ $25^{\circ} \mathrm{C}$ at low light intensity on a rotary shaker at $100 \mathrm{rpm}$. Cell suspensions were subcultured fortnightly by replacing approximately two-thirds of the medium with fresh LS medium.

Data collected from the above experiments were subjected to statistical analysis, including analysis of variance (ANOVA).

Isolation of protoplasts

Protoplasts were isolated from granular callus, one week after subculture, and log phase embryonic cell suspensions. Different enzyme combinations were evaluated including Cellulysin (Sigma-Aldrich, USA), Onozuka RS (Yakult Honsha Co., Ltd.), Onozuka R10 (Yakult Honsha Co., Ltd.), Macerozyme R-10 (Yakult Honsha Co., Ltd.), Driselase (Sigma-Aldrich, USA) and Pectolyase (Sigma-Aldrich, USA). The enzyme solutions were dissolved in $0.6 \mathrm{M}$ mannitol, $80 \mathrm{mM} \mathrm{CaCl}_{2} \cdot 2 \mathrm{H}_{2} \mathrm{O}, 5 \mathrm{mM}$ MES at $\mathrm{pH} 5.8$ and filter sterilised before use. To isolate protoplasts, $100 \mathrm{mg}$ (FW) of cell suspension was incubated in $5 \mathrm{~mL}$ of enzyme solution on a gyratory shaker at $40 \mathrm{rpm}$, in the dark at $25^{\circ} \mathrm{C}$ for $6 \mathrm{~h}$.

The protoplasts were filtered through a $45 \mu$ m nylon mesh and centrifuged for 5 min at $85 \mathrm{x}$ g. The protoplast pellet was re-suspended and washed twice in washing solution containing $80 \mathrm{mM} \mathrm{CaCl}_{2} .2 \mathrm{H}_{2} \mathrm{O}, 5 \mathrm{mM}$ MES, and $0.6 \mathrm{M}$ mannitol at $\mathrm{pH} 5.8$. The protoplasts were counted with a haemocytometer to enable determination of yield. Viability of the protoplasts was tested using fluorescein diacetate (FDA).

Culture of protoplasts

Four different methods were tested for the culture of protoplasts: liquid cultures, embedding cultures, nurse cultures, and culture on nitrocellulose membranes $(0.8 \mu \mathrm{m}$, Millipore) with feeder layers. The protoplasts were cultured on LS, $1 / 2 \mathrm{LS}$, modified LS (MLS) (Yamada et al. 1986) and PELB (Pelletier et al. 1983) with 2,4-D, naphthalene acetic acid (NAA) and benzyl amino purine (BAP) as the growth hormones. Sterile 24well plates were used for liquid cultures and sterile plastic petri dishes $(9 \mathrm{~cm}$ diameter $\mathrm{x}$ 
$1 \mathrm{~cm}$ high) were used for the remaining cultures. The protoplasts were cultured in darkness at $25^{\circ} \mathrm{C}$ for 2 weeks. Plating efficiency (PE\%) was calculated using the formula:

$\mathrm{PE}=$ no. of microcolonies formed/no. of protoplasts plated $\times 100$

Plant regeneration

The colonies formed were plated on LS medium supplemented with 2,4-D and BAP at different concentrations from 0.1 to $1.0 \mathrm{mg} / \mathrm{L}$ for regeneration of shoots. Colonies were cultured in low light intensity and were subcultured every two weeks.

\section{Results and discussion}

Induction of callus and cell suspension

L. perenne contains the fungal endophyte Neotyphodium lolii (Glen et al. 1996).

Therefore sterilisation procedures had to be improved in order to prevent contamination during initiation of callus induction. It was found that 3\% Na-hypochlorite for $60 \mathrm{~min}$ yielded 100\% axenic cultures (Table 1). This is a much higher sodium hypochlorite concentration than usually used for surface-sterilisation of plant tissue. Higher concentrations yielded similar results without any loss of seed viability. When the surface-sterilised germinating embryo was plated on LS medium, it was observed that 5 and $7.5 \mathrm{mg} / \mathrm{L}$ 2,4-D gave the highest percentage of callus induction from seeds with and without the seed coat. However, removal of the seed coat led to a better response in callus induction, with 39\% of seeds producing callus with $5 \mathrm{mg} / \mathrm{L}$ of 2,4-D.

Table 1: Axenic status ( $\% \pm$ S.E.) of $L$. perenne seeds after surface-sterilisation treatments.

\begin{tabular}{lllll}
\hline $\begin{array}{l}\text { Time } \\
(\mathrm{min})\end{array}$ & \multicolumn{4}{l}{ Na-hypochlorite concentration (\%) } \\
\cline { 2 - 5 } & 0.75 & 1.5 & 3.0 & 3.5 \\
\hline 10 & $12.3 \pm 2.5$ & $25.7 \pm 3.2$ & $36.0 \pm 5.3$ & $54.5 \pm 3.7$ \\
30 & $12.3 \pm 2.1$ & $28.7 \pm 1.1$ & $58.0 \pm 6.9$ & $90.2 \pm 5.3$ \\
60 & $15.7 \pm 2.8$ & $30.0 \pm 2.0$ & $100.0 \pm 0.0$ & $100.0 \pm 0.0$ \\
90 & $22.3 \pm 5.5$ & $64.7 \pm 6.2$ & $100.0 \pm 0.0$ & $100.0 \pm 0.0$ \\
\hline
\end{tabular}

S.E. $=$ standard error; number of seeds per treatment $=100$.

Isolation of protoplasts

Vigorously growing granular cell suspensions were used for protoplast isolation. Embryonic cell suspensions have been used previously for protoplast isolation from $L$. perenne (Zaghmout and Torello 1990, Wang et al. 1995). Five different enzyme combinations were evaluated for the isolation of protoplasts. Cellulysin and Onozuka R10 failed to yield a sufficient number of protoplasts $\left(<4 \times 10^{3} / \mathrm{g} \mathrm{FW}\right)$ for isolation and culture. Protoplast yield was increased when Onozuka RS was used instead of Cellulysin or Onozuka R-10. Among the different enzyme combinations used, a high yield of protoplast of $1.1 \times 10^{7} \mathrm{~g}^{-1} \mathrm{FW}$ with a viability of $82 \%$ was obtained when combination of Onozuka RS 2\%, Macerozyme R-10 1\%, Driselase 0.5\% and Pectolyase $0.2 \%$ was used with an incubation period of 6-10 h. Analysis of variance established that the yield of protoplasts and viability was significantly higher with the above enzyme combination than with the other enzyme combinations $(P<0.001)$. The yields 
were comparatively low from these other combinations, even after a prolonged incubation period of $24 \mathrm{~h}$.

Culture of protoplasts and regeneration of plants

Plant regeneration from protoplasts has been achieved in most monocotyledonous species tested to date. However, except for rice, it is still difficult to obtain high plant regeneration frequencies from protoplasts of grasses and cereals. In the present study we used different culture techniques in order to evaluate and analyse plant regeneration from the protoplasts. Of the different culture-media systems studied, cell division was seen only in LS and PELB media. The highest percentage plating efficiency of $0.15 \%$ was recorded in PELB on a nitrocellulose membrane with feeder layer. Colony formation was seen only in protoplasts cultured on LS and PELB media on nitrocellulose membranes with an actively growing $L$. perenne cell suspension as the feeder-layer. This suggests that growth-enhancing factors being released by the feeder layers actively support the division of protoplasts and callus formation. These results support the earlier conclusions of Tang et al. (2000) about the use of a membrane filternurse culture technique for regeneration of plants from cell suspension-derived rice protoplasts. The current study also proves that conditioning factor from L. perenne cell suspension feeder-layer enhances the plating efficiency. Such observations about the positive effects of conditioned medium on the plating efficiencies were previously made in Zea mays (Birnberg et al. 1988), Dactylis glomerata (Horn et al. 1988) and L. perenne (Cremeers-Molenaar et al. 1992).

The callus colonies formed were plated on LS medium supplemented with 0.1 $\mathrm{mg} / \mathrm{L} 2,4-\mathrm{D}$ and $0.1 \mathrm{mg} / \mathrm{L}$ BAP for plant regeneration. Shoots were regenerated from $22 \%$ of the protoplast-derived callus colonies. However, the plants regenerated were albino. Wang et al. (1995) observed that green plants could only be regenerated from protoplasts isolated from young embryogenic cell suspension. Therefore the possible reason for the albino shoots could be that the cell suspension had lost its ability to produce green plants.

In conclusion, this research has described the process of establishment of callus and cell suspension cultures for protoplast isolation. In addition, callus derived from protoplasts was obtained with the nitrocellulose membrane-feeder layer technique. This protocol could be used in further experiments such as somatic hybridisation involving protoplasts of L. perenne. Future research will concentrate on the regeneration of the green plants by using young embryonic cell suspension for the isolation of the protoplasts.

\section{Acknowledgements}

The authors would like to thank Pastoral Genomics, New Zealand and the Foundation for Research Science and Technology, New Zealand (FRST) for providing financial assistance in the form of an Enterprise Scholarship to SV Raikar during this project.

\section{References}

Birnberg PR, Somers DA, Brenner ML (1988) Characterization of conditioning factors that increase colony formation from black Mexican sweet corn protoplasts. Journal of Plant Physiology 132, 316-321.

Burgon A, Bondesen OB, Verburgt WH, Hall AG, Bark NS, Robinson M, Timm G (1997) The forage seed trade. In 'Forage seed production. 1. Temperate species'. (Eds DT Fairey, JG Hampton) pp. 271-286. (CABI Wallingford). 
Creemers-Molenaar J, van Eeuwijk FA, Krens FA (1992) Culture optimization for perennial ryegrass protoplasts. Journal of Plant Physiology 139, 303-308.

Dalton SJ, Bettany AJE, Timms E, Morris P (1999) Co-transformed diploid Lolium perenne (perennial ryegrass), Lolium multiflorum (Italian ryegrass) plants produced by microprojectile bombardment. Plant Cell Reports 18, 721-726.

Glenn AE, Bacon CW, Price R, Hanlin RT (1996) Molecular phylogeny of Acremonium and its taxonomic implications. Mycologia 88, 369-383.

Horn ME, Conger BV, Harms CT (1988) Plant regeneration from protoplasts of embryogenic suspension cultures of orchard grass (Dactylis glomerata L.). Plant Cell Reports 7, 371-374.

Linsmaier EM, Skoog F (1965) Organic growth factor requirements of tobacco tissue cultures. Physiology Plantarum 8, 100-127.

Pelletier G, Primard C, Vedel F, Chetrit P, Remy R, Rouselle P, Renard M (1983) Intergeneric Cytoplasmic Hybridization in Cruciferae by Protoplast Fusion. Molecular \& General Genetics 191, 244-250.

Sharma HC, Crouch JH, Sharma KK, Seetharama N, Hash CT (2002) Applications of biotechnology for crop improvement: prospects and constraints. Plant Science 163, 381-395.

Spangenberg G, Wang ZY, Wu XL, Nagel J, Potrykus I. (1995) Transgenic perennial ryegrass (Lolium perenne) plants from microprojectile bombardment of embryogenic suspension cells. Plant Science 108, 209-217.

Tang K, Sun X, An D, Power JB, Cocking EC, Davey MR (2000) Plant regeneration from protoplasts of a commercial Asian long-grain javanica rice. Plant Cell Tissue and Organ Culture 60, 79-82.

Wang ZY, Legris G, Valles MP, Potrykus I. Spangenberg G (1995) Plant regeneration from suspension and protoplast cultures in the temperate grasses Festuca and Lolium. In 'Current Issues in Plant Molecular and Cellular Biology'. (Eds Terzi M et al.) pp 81-86. (Kluwer Academic, Netherlands)

Wang GR, Binding H, Posselt UK (1997) Fertile transgenic plants from direct gene transfer to protoplasts of Lolium perenne L. and Lolium multiflorum Lam. Plant Physiology 151, 83-90.

Yamada Y, Yang ZQ, Tang DT (1986) Plant regeneration from protoplast-derived callus of rice (Oryza sativa L.) Plant Cell Reports 5, 85-88.

Zaghmout OMF, Torello WA (1990) Isolation and culture of protoplasts from embryogenic suspension cultures of red fescue (Festuca rubra L.). Plant Cell Reports 9, 340-343. 